\title{
ANTHOLOGIZING POE. EDITIONS, TRANSLATIONS, AND (TRANS)NATIONAL CANONS EMRON ESPLIN AND MARGARIDA VALE DE GATO, EDITORS \\ Lehigh University Press, 2020, pp. 401. ISBN: 9781611462586.
}

\author{
JOSE MANUEL CORREOSO RÓDENAS \\ Universidad de Castilla-La \\ Mancha \\ jcorreos@ucm.es
}

Received 5 April 2021

Accepted 7 April 2021

Anthologizing Poe. Editions, Translations, and (Trans)National Canons is the last addition to the vast Poe scholarship developed and published by Lehigh University Press (within their collection Perspectives on Edgar Allan Poe). After other similar titles such as Translated Poe (edited by Emron Esplin and Margarida Vale de Gato) or Poe's Pervasive Influence (edited by Barbara Cantalupo), among others, this volume comes to complete the comprehension of the global impact of Edgar Allan Poe and his works.

The volume we are reviewing here is divided into four different sections, covering respectively the earlier anthologies of Poe's works during the 1840s, the collections that have been produced in the US, the UK, and the Anglophone context in general, specific anthologies based on genre and format, and how Poe has been anthologized in foreign contexts. By choosing such a division, the editors have been capable of collecting and addressing the most relevant perspectives considered by contemporary Poe scholars from different points of the planet.

Within the first mentioned section of the book, three chapters are included. The first of them (by Jana L. Argersinger) opens, as probably could not be done otherwise, with the labor Poe developed as editor of anthologies when working in different literary magazines, but also on how Griswold and Osgood contributed to coin a 
(distorted) vision of Poe through their own anthologies. From there we move to the importance Poe himself placed on the editions of his own works during his lifetime. The chapter signed by Harry Lee Poe explores the different Poe collections published before 1849, how they contributed to assemble the first image of the author in America, and to what extent he was involved in the process. From the earliest moments of Poe's poetic production, the author of the chapter analyzes the different stories that appeared in the subsequent years, categorizing them, and contrasting them with the other texts that were included in the same volumes. By doing so, Harry Lee Poe adapts Poe's unity of effect to his own literary criticism. Finally, the section closes with Alexandra Urakova's chapter. As an acclaimed Russian scholar of Poe, the expectancy for her chapter is high, and accomplished. Her approach to how "Eleonora" has been anthologized probably lies among the most original ones included in the volume. Urakova's analysis does not only perform a philological approach but can also be inserted within an exercise of literary history. Her chapter explores the tradition of the "gift books" in Britain and the United States and how "Eleonora," due to the idyllic-like characteristics of its plot, was usually included in these collections during the first half of the $19^{\text {th }}$ century.

As previously mentioned, the second part of the book is devoted to anthologies and editions in English, and it opens with a chapter by Jeffrey A. Savoye. Savoye's arguments soon change to the depiction of the "race" that took place in the late $19^{\text {th }}$ and early $20^{\text {th }}$ centuries to offer the best possible version of Poe's texts. This first chapter of the section closes at the mid-twentieth century, when Mabbott's edition started to be framed. Savoye's vision is completed with the chapter of another independent scholar, Bonnie Shannon McMullen. While the previous chapter mostly focused on American editions, McMullen's assessments cross the Atlantic and explores how a similar "race" was taking place in Britain. The main difference would be that British editors did not want a definitive edition, but to offer a general view of the author, usually "polluted" by the local imagination. The baton is there received by Travis Montgomery, who journeys through the most relevant scholarly editions produced during the past century. Names such as Ostrom, Pollin, Quinn, Mabbott, and Thomson, are familiar to those who have ever approached the historical fortune of Poe's production. As these critics almost coincided in time, their editions are a constant update of how Poe's tales, poems, and other pieces should be addressed. The 
chapter closes with a commentary of the editions of Poe's texts published by The Library of America. Although lacking the critical apparatus the other volumes had, they still stand as a primary source when dealing with Poe and his works. This vision is completed by Scott Peeples's chapter, which focuses on the Poe texts usually included in university textbooks. Confronting the view of the scholar with the reception of the student is an interesting exercise, for through this exercise we get a whole vision of how Poe has lived (and still lives) in colleges. Perhaps, the most independent chapter of the section is that written by J. Gerald Kennedy, in which a critical approach to the Penguin Portable Edgar Allan Poe is included. Although this anthology has been transcendental to get new readers involved in a certain connoisseurship of Poe, we cannot forget it responds to a particular view published in a particular context, as Kennedy assesses.

The next section within Anthologizing Poe includes chapters focused on genre and format. Probably, the only thing-that-couldhave-been-done-otherwise in the volume relates to the inclusion of this section. Perhaps, confronting English anthologies with foreign editions would have contributed to give the reader a clearer scope of Poe's influence both at home and worldwide. As known, Poe has widely contributed to the modern evolution of science-fiction, and that is acknowledged in Stephen Rachman's chapter, which discusses anthologies focused on this genre and under the title of Bradbury's "Usher II." The 20 ${ }^{\text {th }}$ century has been a domain for science-fiction, and Poe has taken advantage of this circumstance, being included in most of the volumes (at least in English) produced during those years. Modern detective fiction is also said to be a "creation" of Edgar Allan Poe, so anthologies focused on this genre, almost invariably, need to include the Bostonian, as John Gruesser argues. The most interesting idea offered by Gruesser is that not only Dupin's stories are considered, but also those in which detection and ratiocination are frequently included. Probably, the most original contribution of this section is Michelle Kay Hansen's, for her chapter explores not a textual anthology of Poe's text, but Doug Bradley's recordings or "Spinechillers." Subverting the printed "boundary" is a remarkable exercise, and it allows the reader to approach a similar idea as that of the unity of effect conceived by Poe. Finally, the section closes with Philip Edward Phillips's chapter on Poe's poetry. When discussing how Poe had anthologized himself, poetry is also mentioned, for these were the first texts produced by the Bostonian. 
However, Phillips's perspective goes deeper (including key editions and editors) into the issue, enlarging the scope of the reader and the scholar.

The fourth and last part of the book leaves the Anglophone world behind to explore the global recognition of Poe and his works. Structurally, the section can be divided into three different parts, focused on the French, Hispanic, and Japanese contexts. Chapters 13 and 14 (by Margarida Vale de Gato and Christopher Rollason, respectively) address the French face of Edgar Poe's anthologies, how this country contributed to shape current European visions on the author, being Baudelaire, undoubtedly, a milestone in this process. On its part, Rollason's chapter adds a new piece of information, for it explores how popular editions made Poe a widely read author on both sides of the English Channel, in Britain and France. After that, we have a chapter by Fernando González-Moreno and Margarita Rigal-Aragón and another by Emron Esplin, both focused on the reception and edition of Poe on both sides of the Atlantic, in Spain and Argentina. González-Moreno and Rigal-Aragón, two highly acclaimed international Poe voices, explore how illustrations have also aided to create a comprehensive vision of Poe in Spain, taking advantage of the "visuality" Poe included in many of his stories. On the other hand, Borges and Cortázar count among the most influential twentieth-century Poe "thinkers" and translators, but they are not the only ones Argentina has given. Esplin, continuing with his ongoing extensive research on Poe in Latin America, offers here how the last century has been a melting pot for the editions and translations of the Bostonian around the Rio de la Plata. Finally, this anthology closes with Takayuki Tatsumi's chapter, in which the history of Poe anthologies in Japan is explained. Out of the Eurocentric context, Japan has always been a paradise for Poe's reception, since the times of Lafcadio Hearn and Edogawa Rampo. In consequence, what Tatsumi offers in his chapter is especially relevant, for it links both worlds across the Pacific, bringing American literature to Japan, a journey also frequently traversed due to the influx of popular culture.

In conclusion, as seen in the previous paragraphs, Anthologizing Poe constitutes a landmark in the appreciation of how thousands of readers across generations have approached Poe: anthologies. The subject of this book has not always been the target of academic debate, so Esplin and Vale de Gato have come to offset that by gathering some of the most influential voices on Poe today. 
The result, as explained, is an outstanding collection, with its gaps (as any collection), that the trajectory of the editors shows as easily fixable in a near future. 